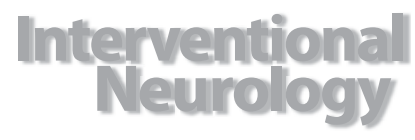

\title{
Deep Brain Stimulation
}

\author{
X.L. Chen Y.Y. Xiong G.L. Xu X.F. Liu \\ Department of Neurology, Jinling Hospital, Nanjing University School of Medicine, \\ Nanjing, China
}

\section{Key Words}

Motor function - Essential tremor · Parkinson's disease · Primary dystonia ·

Obsessive-compulsive disorder · Neurological diseases

\begin{abstract}
Deep brain stimulation (DBS) has provided remarkable therapeutic benefits for people with a variety of neurological disorders. Despite the uncertainty of the precise mechanisms underlying its efficacy, DBS is clinically effective in improving motor function of essential tremor, Parkinson's disease and primary dystonia and in relieving obsessive-compulsive disorder. Recently, this surgical technique has continued to expand to other numerous neurological diseases with encouraging results. This review highlighted the current and potential future clinical applications of DBS.

(c) 2013 S. Karger AG, Basel
\end{abstract}

\section{Introduction}

The modern era of deep brain stimulation (DBS) began in 1987 with the pioneering work by Benabid et al. [1] on the treatment of Parkinson's disease (PD). The discovery that electrical stimulation of functional targets was able to mimic (in a reversible and adjustable manner) a lesion-like effect has revived the use of functional neurosurgery for movement disorders [2]. Despite the fact that the underlying therapeutic mechanisms of DBS remain mysterious and controversial [3], it has been used as an effective therapy for an increasingly expanding spectrum of neurological diseases. Up to now, DBS has largely replaced ablative procedures for the treatment of advanced essential tremor (ET), PD and primary dystonia. It is also approved for the treatment of obsessive-compulsive disorder (OCD) [4]. Scientific efforts to explore the mechanisms of action of DBS are in progress. Meanwhile, clinical 
researchers continue excavating the potential effects of DBS in other brain disorders and defining optimal targets. Here we gave an overview of the current clinical applications and the potential future development of DBS.

\section{Mechanisms of DBS}

The therapeutic effects of DBS involve a variety of mechanisms. Stimulation through an electrode placed within a nuclear region will affect several neuronal components including cell bodies, axons and fibers of passage, generating an inhibitory synaptic effect on the cells but a concurrent high-frequency effect on efferent axons and fibers $[3,5]$. The therapy modulates pathological network activity beyond local neuronal cell bodies and axons, either monosynaptic or polysynaptic, through its electrical, chemical and other neural network influences. DBS changes the firing rate and pattern of individual neurons in the basal ganglia [6] and eliminates abnormal rhythmic oscillation between the cortex and the basal ganglia [7]. The electrical current also acts on synapses and triggers adjacent astrocytes to release a wave of calcium and to promote local release of neurotransmitters (e.g. adenosine and glutamate) from excitatory efferent neurons [8-10]. In addition, this intervention produces global increases in cerebral blood flow [11] and stimulates neurogenesis [12]. All these effects of DBS depend on a number of parameters, including amplitude and temporal characteristics of the stimulation, physiological properties of the targeted cells, geometric configuration of the electrode and the surrounding tissue, and possibly the underlying pathophysiology of different disease states [13]. The most likely mode of action so far suggests that network-wide modulatory effects of DBS mediate its clinical effects. However, it still remains unclear exactly how these influences lead to changes in the symptoms of a certain neurological disease. Therefore, the foundation of this therapy has been more or less empirical.

\section{Clinical Applications of Deep Brain Stimulation}

DBS was approved by the US Food and Drug Administration as a treatment for ET in 1997, PD in 2002, primary dystonia in 2003 and OCD in 2009. For each of these conditions, DBS is considered when nonsurgical management has failed. DBS is also routinely used in the treatment of chronic pain and various psychiatric disorders, including epilepsy, chronic pain, depression, Tourette syndrome (TS), Huntington's disease, obesity and addictions, Alzheimer's disease (AD) and consciousness disorders.

\section{Essential Tremor}

ET is the most common neurological movement disorder, typically recognized as involuntary rhythmic movements of the limbs, but it can also affect the head, neck, voice and other body regions. The idea of reducing tremor with DBS began to emerge in the 1960s [14], and treatment of tremor associated with ET or PD witnessed the first widespread use of DBS. The ventral intermediate nucleus of the thalamus is the most widely agreed target for treating ET with DBS $[15,16]$, with an average tremor control of over $80 \%$ in these patients [17-19]. Other investigators have suggested that the subthalamic region, posterior subthalamic area and caudal zona incerta nucleus may also be an effective target for ET [20-22]. The technique is, however, limited in some ET patients by relevant side effects such as dysarthria, disequilibrium and paresthesia. Bipolar configuration is proven to have fewer side effects, and stimulation at $90 \mu \mathrm{s}, 130 \mathrm{~Hz}$ and voltage up to $3 \mathrm{~V}$ tends to be effective and well tolerated [23]. Such parameters are, nevertheless, highly variable among patients to optimize tremor con- 
trol. DBS for the management of midline tremor (head, voice, tongue and trunk) is less effective and generally requires bilateral stimulation for optimal results. Thalamic DBS, compared with thalamotomy, was shown to have significantly functional improvement of tremor with fewer adverse effects, making it a preferential surgical choice for medically refractory ET [24, 25].

\section{Parkinson's Disease}

PD affects approximately $0.3 \%$ of the general population. The cardinal features of PD are resting tremor, rigidity, bradykinesia and postural instability. In the course of the disease, about $40 \%$ of patients will develop marked motor 'on-off' fluctuations and drug-induced dyskinesias after 5 years of medical treatment [26]. Hyperactivity of the subthalamic nucleus (STN) and globus pallidus internus (GPi) is substantiated to be part of the pathophysiological mechanism of PD [27], making them the most commonly targeted sites for DBS in PD. DBS of GPi and STN to treat patients with PD was first reported by Siegfried and Lippitz [28] in 1994 and Limousin et al. [29] in 1995, respectively. Since then, DBS surgery has emerged worldwide in the treatment of PD. Long-term, high-quality evidence is available for stimulation of STN and $\mathrm{GPi}$, and both provide a similar reduction of motor symptoms [30-32]. Typically, levodoparesponsive symptoms, dyskinesias, tremor and on-off fluctuations are most likely to improve with DBS, remaining stable for at least 4 years, whereas impairments in speech, balance, gait and cognition are less likely to improve and may in some cases worsen postoperatively [3335]. Despite the controversy of its effect on cognitive functions and psychiatric side effects, STN DBS is usually favored over GPi DBS for a significantly decreased daily dose of dopaminergic medications and a better outcome of motor signs [36, 37]. Other stimulation targets, such as the pedunculopontine nucleus and the centromedian/parafascicular thalamic complex, have only short-term evidence and still require further investigation [38]. Good candidates for DBS are those who have adequate dopaminergic response while showing on-off fluctuations, dyskinesia and medication-resistant tremor with reasonable cognitive function [39]. DBS at an earlier stage of PD has also showed benefit, but was based on a small population and further verification is necessary [40]. Settings that are used for DBS are, typically, high frequency $(130-185 \mathrm{~Hz})$ with pulse widths of $60-120 \mu$ s at voltages ranging from 2.0 to $5.0 \mathrm{~V}$, but these are highly variable among patients, with frequent adjustment during the first few months after implantation $[39,41]$.

Randomized controlled clinical trials have been performed to check the effectiveness of DBS therapy. Three trials have made comparisons with medical therapy [42-44]. The primary end points were mainly the following: (1) the quality of life, as assessed by the Parkinson's Disease Questionnaire (PDQ-39; scores ranging from 0 to 100, with higher scores indicating poorer function) [45], (2) the severity of symptoms without medication, according to the Unified Parkinson's Disease Rating Scale, part III (UPDRS-III; scores ranging from 0 to 100, with higher scores indicating worse condition) [46] and (3) time spent daily in the 'on' state without dyskinesia. In a trial involving 156 patients with advanced PD and severe motor symptoms in Germany and Australia, with 6 months of follow-up, patients who underwent STN DBS gained significantly better mean scores on the PDQ-39 (31.8vs. 40.2) and the UPDRSIII (28.3 vs. 46.0) [42]. A trial conducted in the US enrolled 255 patients with 6 months of follow-up, and patients who received DBS of STN or GPi had a mean of $4.6 \mathrm{~h}$ per day of 'on' time compared with $0 \mathrm{~h}$ per day for the best medical therapy group [43]. In another trial involving 366 patients in the UK, at 1 year the mean PDQ-39 score was 32.5 among patients undergoing STN DBS versus 38.1 among those receiving best medical therapy [44]. To compare the therapeutic efficacy of STN or GPi, two trials have been performed [31, 47], showing no significant between-group differences in the optimal DBS state at 7 and 24 months, respectively. One trial involving 20 patients with PD of short duration with mild-to- 
moderate motor signs showed significantly improved life quality and motor function in the STN stimulation group compared with the medical treatment group after 18 months, indicating DBS to be a therapeutic option early in the course of PD [40].

\section{Primary Dystonia}

Primary dystonia is a debilitating movement disorder with a widespread spectrum mainly in young people. It is characterized by sustained muscle contractions, causing repetitive twisting movements or abnormal postures [48]. Medical treatments of botulinum toxin, anticholinergic agents, muscle relaxants, benzodiazepines and levodopa are available, but are limited by poor efficacy and tolerability [49]. Since the early report of DBS in dystonia treatment [50], it has been increasingly proved to provide marked benefit for refractory dystonia with the generally accepted target of GPi [51,52].

GPi DBS has been established as an effective surgical treatment alternative for primary dystonia, with a 50-80\% motor benefit according to short-term [53, 54] and long-term longitudinal studies [55-58]. In a randomized controlled trial by Kupsch et al. [53], 40 patients with primary dystonia were randomly assigned to either bilateral GPi DBS or sham stimulation (in which the device was implanted but not activated) for 3 months; thereafter, all patients completed 6 months of DBS therapy and were followed annually with a 5-year follow-up period $[53,58]$. Dystonia severity was assessed by the Burke-Fahn-Marsden Dystonia Rating Scale (BFMDRS), consisting of motor (BFMDRS-M) and disability (BFMDRS-D) subscales [59]. Treated patients improved significantly more than controls (39.3 vs. 4.9\%) in the BFMDRS-M subscale; similar improvements can be noted when sham stimulation was switched to active stimulation [53]. Dystonia severity improved by $47.9 \%$ in 40 patients at 6 months, then to an overall $61.1 \%$ in 38 patients at 3 years, and to a $57.8 \%$ improvement in 32 patients who were available for follow-up at 5 years [58]. One similar controlled trial demonstrated that DBS provided sustained motor benefit after 3 years, with BFMDRS-M score improved by $51 \%$ at 1 year and still maintained at 3 years (58\%); in addition, mild long-term improvements in quality of life and attention were also observed [54,57]. Another study of 23 patients reported that BFMDRS-M scores improved by $79.6 \%$ at 1 year and by $82.5 \%$ at 2 years, and these scores were maintained for up to 8 years postoperatively [55]. A retrospective study involving 44 patients drawn from five experienced DBS centers also showed BFMDRS improvement with DBS treatment, with $74.9 \%$ at 1 year and $82.6 \%$ at 3 years [56].

Patients with primary generalized or segmental dystonia who do not achieve sufficient relief with conservative approaches are best candidates for GPi DBS therapy. Those with cervical dystonia who have failed medical management are also good DBS candidates, whereas DBS is less effective in secondary dystonia patients with the exception of tardive dystonia [48]. Younger patients with shorter duration of disease may expect a better general outcome independent of the age of onset, severity of disease, early-onset primary dystonia status and the presence of phasic or tonic involuntary movements $[56,60]$.

\section{Obsessive-Compulsive Disorder}

OCD is a chronic psychiatric disorder manifested by obsessional ideas, compulsive behaviors and repetitive rituals, with a prevalence of 1.2-2.3\% [61]. Current treatment generally uses a combination of serotonin reuptake inhibitors and cognitive behavioral intervention. However, up to $40-60 \%$ of OCD patients are resistant to these treatments [62] and $20-40 \%$ will have persistent symptoms leading to chronic functional impairment [63]. For the highly refractory OCD patients, ablative neurosurgical stereotactic treatments have been attempted, and since the first report in 1999 by Nuttin et al. [64], DBS has also been investigated. 
Surgical approaches for OCD treatment provide targets of subcaudate tractotomy, cingulotomy, limbic leucotomy and anterior capsulotomy for neuroablative surgery or tractotomy [65], but the optimal target for DBS still needs to be determined for the deficiency of a clearly elucidated pathophysiological mechanism of OCD disorder [66-68]. Potential targets for OCD DBS in previous reports included the anterior limb of the internal capsule, ventral capsule/ ventral striatum, nucleus accumbens (NAc), STN and inferior thalamic peduncle [69]. Generally, two major targets have been studied: the anterior limb of the internal capsule extending to adjacent ventral striatum and the STN. The internal capsule was introduced by the first DBS for the OCD series [64], and long-term outcomes have shown promising effects using the anterior limb of the internal capsule $[70,71]$ and ventral capsule/ventral striatum [72] as the stimulating targets. STN as a stimulating target was inspired from beneficial effects of STN DBS observed in PD patients suffering from OCD as well $[73,74]$. STN DBS may lessen the severity of OCD symptoms and improve global functioning, but serious complications like suicidal ideation should be cautioned [75]. Long-term effects of STN DBS for patients with OCD are yet to be determined.

\section{Epilepsy}

Epilepsy is one of the most prevalent and disabling disorders characterized by recurrent unprovoked seizures, affecting $0.5-1 \%$ of the population annually [76]. Over $30 \%$ of the cases are pharmacoresistant, and they currently have relatively limited alternative treatment options such as resection [77] and vagus nerve stimulation [78]. Since the pioneering study by Cooper et al. [79] to influence epilepsy by cerebellar DBS in the early 1970s, the efficacy of DBS in the treatment of intractable epilepsy has been increasingly investigated. Up to now, DBS has been applied to several efficient targets [80] including the cerebellum, caudate nucleus, centromedian thalamus, anterior thalamus, STN and hippocampus, among which only DBS of the anterior thalamus now has class I evidence. It has favorable results from the SANTE (Stimulation of the Anterior Nucleus of Thalamus for Epilepsy) trial supporting its use and is approved by the European Union for treating epilepsy [81]. Typical settings for stimulation are 1-10 V with $90 \mu$ s pulses in trains of 100-165 Hz, running either continuously or $1 \mathrm{~min}$ on and $5 \mathrm{~min}$ off, but which can be reprogrammed to maximize clinical affect and minimize side effects [82]. Overall, DBS therapy is quite promising for reduction in seizure in patients with partial seizures and medically refractory epilepsy.

\section{Chronic Pain}

The main applications for DBS during the 70s and 80s were actually for chronic pain [83]. For over half a century, DBS has proven effective for treating a variety of neuropathic and nociceptive pain states that are not responsive to other neuromodulation techniques, including cluster headaches, chronic low back pain, failed back surgery syndrome, peripheral neuropathic pain, facial deafferentation pain and pain that is secondary to brachial plexus avulsion [84]. Benefit varies depending on the etiology, length of follow-up, definition of adequate pain relief and the site of stimulation [85]. Stimulation sites included the periventricular/periaqueductal grey matter [86], the internal capsule [87], the sensory thalamus [88] and the posterior hypothalamus [89]. The use of periventricular/periaqueductal grey matter stimulation is generally recommended for nociceptive pain and sensory thalamus DBS for deafferentation pain [90], whereas DBS of the posterior hypothalamus is an effective approach to treat refractory chronic cluster headache [91]. A meta-analysis was performed to determine the long-term efficacy of DBS in the treatment of chronic pain and found that the long-term success rate ranged from 19 to $79 \%$ with a downward tendency as the length of follow-up increases [85]. Therefore, despite evidence of efficacy [92], DBS remains off-label and investigated. 


\begin{tabular}{l|l}
\hline DOI: $\underline{10.1159 / 000353121}$ & $\begin{array}{l}\text { C } 2013 \text { S. Karger AG, Basel } \\
\text { www.karger.com/ine }\end{array}$ \\
\hline
\end{tabular}

Chen et al.: Deep Brain Stimulation

\section{Depression}

Major depressive disorder as a widely distributed illness is presented with a lifetime prevalence rate of more than $12 \%$ in men and $20 \%$ in women [93]. Up to $20 \%$ are treatmentresistant depression (TRD), which has prompted the investigation of alternative treatment strategies. The initiate study of DBS in the treatment of TRD found that chronic stimulation of the subgenual cingulate white matter improved mood in 4 of 6 patients [94]. Likewise, another target located in the subcallosal cingulate gyrus has provided sustained benefit for DBS treatment of TRD with a mean reduction in the Hamilton Depression Rating Scale of 52\% after 1 year [95, 96]. Kennedy et al. [97] demonstrated that DBS to the same area remained a safe and effective treatment for TRD after 3-6 years of follow-up. A single case report suggested the inferior thalamic peduncle was also an efficient target to relieve depressive symptoms [98]. In addition, the caudate nucleus [99], ventral capsule/ventral striatum area [100], NAc [101] and lateral habenula [102] have been suggested as effective DBS targets for TRD. Overall, DBS is a promising but experimental therapy for TRD and should only be administered by multidisciplinary teams.

\section{Tourette Syndrome}

TS is a childhood-onset neuropsychiatric disorder with a prevalence of nearly $1 \%$ for children worldwide [103]. It is typically characterized by multiple physical (motor) and at least one phonic (vocal) tics lasting longer than 1 year. Despite a wide therapeutic spectrum, severely affected patients respond poorly to medication. Several series have reported on the effectiveness of DBS for TS treatment, and at the present time, DBS is recommended only in adult, treatment-resistant and severely affected patients [104].

The centromedial parafascicular complex of the thalamus has been the first and remains the most used target for the treatment of intractable TS by DBS [105-108]. Since then, other targets, including the GPi (the posteroventrolateral and the anteromedial part) $[105,108]$, the STN [109], the crosspoint of the thalamic centromedian nucleus-substantia periventricularis-nucleus ventrooralis internus [110], the NAc [111] and the anterior limb of the internal capsule [112] have been used, or a combination of different targets [113]. However, data were insufficient to determine whether one of these targets is superior to another since all targets belong to the ventral striatal-thalamo-cortical circuitries, which are thought to be dysfunctional in TS. Besides, all patients have had some degree of tic reduction with DBS in these targets.

\section{Huntington's Disease}

Huntington's disease is an autosomal dominant disease which produces debilitating motor abnormalities that are poorly responsive to medical therapy. Moro et al. [114] reported the first case study showing that bilateral GPi DBS has the potential to improve chorea without aggravating bradykinesia. Other case reports further investigated the long-term effects and showed a sustained alleviation of Huntington's disease-associated choreathetosis $[115,116]$, while it may cause deterioration in motor function and cognition [117]. With these few clinical reports, the precise selection criteria and optimal stimulation parameters remain to be further defined.

\section{Obesity and Addictions}

Obesity is a growing health problem worldwide and DBS has been used in obese patients [118]. The primary DBS attempted to modulate the homeostatic mechanisms of weight control (the satiety center of the ventromedial hypothalamus and the feeding center of the lateral hypothalamus) but gained limited success $[119,120]$. Other authors have proposed regions of the brain's reward circuitry, such as the NAc, as promising alternatives for DBS in 
obesity control [121]. Specifically, low-frequency stimulation $(50 \mathrm{~Hz})$ led to initial weight loss but was followed by regaining of the weight [122]. One analysis has suggested that DBS must achieve a success rate of $83 \%$ to be equivalent to bariatric surgery [123]. Interestingly, obesity was also observed as a complication in PD patients after they underwent STN DBS [124]. Besides obesity, smoking, alcoholism and other drug addictions have been reported to improve after NAc DBS [125-127].

\section{Alzheimer's Disease}

$\mathrm{AD}$ is an increasingly prevalent degenerative disorder causing a range of progressive neuropsychiatric symptoms and cognitive deficits [128]. Due to the limited effectiveness of current treatment, novel therapeutic approaches are needed. Hamani et al. [122] observed memory enhancement in a patient who underwent fornix/hypothalamus DBS for obesity. This gives impetus to a phase I trial of DBS in 6 patients with mild AD, which found possible improvements or slowing in the rate of cognitive decline at 6 and 12 months after DBS; in addition, increased glucose metabolism was observed in the temporal and parietal cortical areas both at the 1-month and 1-year follow-up [129]. Another open-label trial involving 5 mild AD patients also found persistent cortical metabolic increases after 1 year of DBS that were associated with better clinical outcomes, providing evidence that DBS resulted in changes to neural circuitry and enhanced functional connectivity; these results were more effective than pharmacotherapy in AD [130]. Given the destructive nature of AD and cognitive improvements of DBS therapy, future studies investigating the appliance of DBS to treat AD are warranted.

\section{Consciousness Disorders}

Severe traumatic brain injury is a leading cause of persistent vegetative state or minimally conscious state as a result of widespread deafferentation and compression injuries to the thalamus and midbrain [131]. Consideration of thalamic DBS to treat patients with severe disorders of consciousness has a long history and has been proved to improve cognitive functioning and behavioral responsiveness in recent studies [132, 133]. DBS for consciousness disorders can be appreciated as a potential option for future clinical research, albeit its offlabel status [134].

\section{Adverse Effects}

Adverse effects of DBS consist of a wide variety of accurate or chronic neurological and neuropsychological complications such as those related to surgery, hardware and stimulation. The major surgery-related risk is intracranial hemorrhage. A recent extensive review suggests that the overall incidence of hemorrhage was 5.0\%, with symptomatic hemorrhage occurring in $2.1 \%$ of patients and hemorrhage resulting in permanent neurological deficit or death in $1.1 \%$ [135]. Postoperative seizures have also been reported and generally occur within $48 \mathrm{~h}$ of surgery [136], with an estimated incidence of $2.4 \%$ [137]. The most common hardware complications include infections, electrode migrations or misplacements, wire fractures, skin erosion and device malfunction [138], and the rate varies greatly between different centers, ranging from 4.3 to $17.8 \%$ [139-143]. Infections are the most reported hardware complications [144], which often require device removal and a period of antibiotic treatment before consideration for device replacement [145]. Surgery- and hardware-related complications could generally be reduced with increased surgical experience and the introduction of new surgical equipment and technology. Stimulation-related adverse effects include muscle contractions, dysarthria, ocular deviations, tremor, dyskinesia, headache, 
pain and paresthesias, which are very useful during intraoperative target exploration and can often be ameliorated by adjustment of stimulation settings or discontinuation of therapy [146]. Verbal fluency is the most common cognitive adverse effect of STN DBS, owing to the effect of surgical electrode implantation rather than stimulation-induced interference [39]. Chronic changes like mania, depression, apathy, panic, impulsivity, anxiety, hallucinations, and even suicidal ideation, are probably multifactored by medication changes, neuronal plasticity following DBS, adaptation difficulties and dramatic sociofamilial modification induced by the motor effects of DBS; they should be screened and managed by a multidisciplinary approach [147].

In general, DBS is a relatively safe approach associated with an encouragingly low rate of adverse effects, which is an effective therapeutic option to assist in a multitude of otherwise treatment-resistant neurological diseases.

\section{Acknowledgments}

This work has been supported by grants from National Natural Science Foundation of China - the Major International (Regional) Joint Research Program of China (Grant Number: 81220108008) and National Natural Science Foundation of China (General program): The role of CXCL12/CXCR4 in the neural stem cells intranasally delivered target to the brain (No. 31171016).

\section{References}

- 1 Benabid AL, Pollak P, Louveau A, Henry S, de Rougemont J: Combined (thalamotomy and stimulation) stereotactic surgery of the VIM thalamic nucleus for bilateral Parkinson Disease. Stereotact Funct Neurosurg 1987; 50:344-346.

2 Benabid AL: What the future holds for deep brain stimulation. Expert Rev Med Devices 2007;4:895-903.

- 3 McIntyre CC, Hahn PJ: Network perspectives on the mechanisms of deep brain stimulation. Neurobiol Dis 2010,38:329-337.

4 Machado A, Fernandez HH, Deogaonkar M: Deep brain stimulation: what can patients expect from it? Cleve Clin J Med 2012;79:113-120.

5 McIntyre CC, Savasta M, Kerkerian-Le Goff L, Vitek JL: Uncovering the mechanism(s) of action of deep brain stimulation: activation, inhibition, or both. Clin Neurophysiol 2004;115:1239-1248.

- 6 Wichmann T, DeLong MR, Guridi J, Obeso JA: Milestones in research on the pathophysiology of Parkinson's disease. Mov Disord 2011;26:1032-1041.

- 7 Brown P, Mazzone P, Oliviero A, Altibrandi MG, Pilato F, Tonali PA, Di Lazzaro V: Effects of stimulation of the subthalamic area on oscillatory pallidal activity in Parkinson's disease. Exp Neurol 2004;188:480-490.

- 8 Lee JY, Kim HJ, Yun JY, Paek SH, Jeon BS: OFF-rebound dyskinesia in subthalamic nucleus stimulation in Parkinson disease. Can J Neurol Sci 2011;38:768-771.

9 Lee KH, Chang S-Y, Roberts DW, Kim U: Neurotransmitter release from high-frequency stimulation of the subthalamic nucleus. J Neurosurg 2004;101:511-517.

10 Tawfik VL, Chang SY, Hitti FL, Roberts DW, Leiter JC, Jovanovic S, Lee KH: Deep brain stimulation results in local glutamate and adenosine release: investigation into the role of astrocytes. Neurosurgery 2010;67:367375.

11 Sidtis JJ, Tagliati M, Alterman R, Sidtis D, Dhawan V, Eidelberg D: Therapeutic high-frequency stimulation of the subthalamic nucleus in Parkinson's disease produces global increases in cerebral blood flow. J Cereb Blood Flow Metab 2012;32:41-49.

12 Vedam-Mai V, van Battum EY, Kamphuis W, Feenstra MGP, Denys D, Reynolds BA, Okun MS, Hol EM: Deep brain stimulation and the role of astrocytes. Mol Psychiatry 2012;17:124-131.

13 Kringelbach ML, Jenkinson N, Owen SL, Aziz TZ: Translational principles of deep brain stimulation. Nat Rev Neurosci 2007;8:623-635.

14 Hassler R, Riechert T, Mundinger F, Umbach W, Ganglberger JA: Physiological observations in stereotaxic operations in extrapyramidal motor disturbances. Brain 1960;83:337-350.

15 Benabid AL, Pollak P, Hoffmann D, Gervason C, Hommel M, Perret JE, de Rougemont J, Gao DM: Long-term suppression of tremor by chronic stimulation of the ventral intermediate thalamic nucleus. Lancet 1991;337: 403-406. 
Chen et al.: Deep Brain Stimulation

-16 Alesch F, Pinter MM, Helscher RJ, Fertl L, Benabid AL, Koos WT: Stimulation of the ventral intermediate thalamic nucleus in tremor-dominated Parkinson's disease and essential tremor. Acta Neurochir 1995;136: 75-81.

17 Koller WC, Lyons KE, Wilkinson SB, Pahwa R: Efficacy of unilateral deep brain stimulation of the VIM nucleus of the thalamus for essential head tremor. Mov Disord 1999;14:847-850.

$\checkmark 18$ Limousin P, Speelman JD, Gielen F, Janssens M: Multicentre European study of thalamic stimulation in parkinsonian and essential tremor. J Neurol Neurosurg Psychiatry 1999;66:289-296.

19 Rehncrona S, Johnels B, Widner H, Tornqvist AL, Hariz M, Sydow O: DBS suppress severe tremor in PD and ET more than 6 years after permanent implantation. Mov Disord 2003;18:163-170.

20 Plaha P, Javed S, Agombar D, O’Farrell G, Khan S, Whone A, Gill S: Bilateral caudal zona incerta nucleus stimulation for essential tremor: outcome and quality of life. J Neurol Neurosurg Psychiatry 2011;82:899-904.

21 Blomstedt P, Sandvik U, Tisch S: Deep brain stimulation in the posterior subthalamic area in the treatment of essential tremor. Mov Disord 2010;25:1350-1356.

22 Plaha P, Patel NK, Gill SS: Stimulation of the subthalamic region for essential tremor. J Neurosurg 2004;101: 48-54.

23 O’Suilleabhain PE, Frawley W, Giller C, Dewey RB Jr: Tremor response to polarity, voltage, pulse width and frequency of thalamic stimulations. Neurology 2003;60:786-790.

24 Schuurman PR, Bosch DA, Bossuyt PM, Bonsel GJ, van Someren EJ, de Bie RM, Merkus MP, Speelman JD: A comparison of continuous thalamic stimulation and thalamotomy for suppression of severe tremor. New Engl J Med 2000;342:461-468.

25 Schuurman PR, Bosch DA, Merkus MP, Speelman JD: Long-term follow-up of thalamic stimulation versus thalamotomy for tremor suppression. Mov Disord 2008;23:1146-1153.

26 Ahlskog JE: Frequency of levodopa-related dyskinesias and motor fluctuations as estimated from the cumulative literature. Mov Disord 2001;16:448-458.

27 Rodriguez-Oroz MC, Jahanshahi M: Initial clinical manifestations of Parkinson's disease: features and pathophysiological mechanisms. Lancet Neurol 2009;8:1128-1139.

-28 Siegfried J, Lippitz B: Bilateral chronic electrostimulation of ventroposterolateral pallidum: a new therapeutic approach for alleviating all Parkinsonian symptoms. Neurosurgery 1994;35:1126-1130.

29 Limousin P, Pollak P, Benazzouz A, Hoffmann D, Le Bas JF, Broussolle E, Perret JE, Benabid AL: Effect on parkinsonian signs and symptoms of bilateral subthalamic nucleus stimulation. Lancet 1995;345:91-95.

30 Anderson VC, Burchiel KJ, Hogarth P, Favre J, Hammerstad JP: Pallidal vs subthalamic nucleus deep brain stimulation in Parkinson disease. Arch Neurol 2005;62:554-560.

-31 Follett KA, Weaver FM, Stern M, Hur K, Harris CL, Luo P, Marks WJ Jr, Rothlind J, Sagher O, Moy C, et al: Pallidal versus subthalamic deep-brain stimulation for Parkinson's disease. New Engl J Med 2010;362:2077-2091.

-32 Nakamura K, Christine CW, Starr PA, Marks WJ Jr: Effects of unilateral subthalamic and pallidal deep brain stimulation on fine motor functions in Parkinson's disease. Mov Disord 2007;22:619-626.

-33 Rodriguez-Oroz MC, Obeso JA, Lang AE, Houeto JL, Pollak P, Rehncrona S, Kulisevsky J, Albanese A, Volkmann J, Hariz MI, et al: Bilateral deep brain stimulation in Parkinson's disease: a multicentre study with 4 years follow-up. Brain 2005;128:2240-2249.

-34 Visser-Vandewalle V, van der Linden C, Temel Y, Celik H, Ackermans L, Spincemaille G, Caemaert J: Long-term effects of bilateral subthalamic nucleus stimulation in advanced Parkinson disease: a four-year follow-up study. Parkinsonism Relat Disord 2005;11:157-165.

-35 Weaver FM, Follett KA, Stern M, Luo P, Harris CL, Hur K, Marks WJ Jr, Rothlind J, Sagher O, Moy C, et al: Randomized trial of deep brain stimulation for Parkinson disease: thirty-six-month outcomes. Neurology 2012;79:55-65.

-36 Moro E, Lozano AM, Pollak P, Agid Y, Rehncrona S, Volkmann J, Kulisevsky J, Obeso JA, Albanese A, Hariz MI, et al: Long-term results of a multicenter study on subthalamic and pallidal stimulation in Parkinson's disease. Mov Disord 2010;25:578-586.

-37 Witt K, Daniels C, Reiff J, Krack P, Volkmann J, Pinsker MO, Krause M, Tronnier V, Kloss M, Schnitzler A, et al: Neuropsychological and psychiatric changes after deep brain stimulation for Parkinson's disease: a randomised, multicentre study. Lancet Neurol 2008;7:605-614.

38 Fasano A, Daniele A, Albanese A: Treatment of motor and non-motor features of Parkinson's disease with deep brain stimulation. Lancet Neurol 2012;11:429-442.

39 Okun MS: Deep-brain stimulation for Parkinson's disease. New Engl J Med 2012;367:1529-1538.

-40 Schüpbach WMM, Maltête D, Houeto JL, du Montcel ST, Mallet L, Welter ML, Gargiulo M, Béhar C, Bonnet AM, Czernecki V, et al: Neurosurgery at an earlier stage of Parkinson disease: a randomized, controlled trial. Neurology 2007;68:267-271.

41 Moro E, Esselink RJ, Xie J, Hommel M, Benabid AL, Pollak P: The impact on Parkinson's disease of electrical parameter settings in STN stimulation. Neurology 2002;59:706-713.

42 Deuschl G, Schade-Brittinger C, Krack P, Volkmann J, Schafer H, Botzel K, Daniels C, Deutschlander A, Dillmann U, Eisner W, et al: A randomized trial of deep-brain stimulation for Parkinson's disease. New Engl J Med 2006; 355:896-908.

43 Weaver FM, Follett K, Stern M, Hur K, Harris C, Marks WJ Jr, Rothlind J, Sagher O, Reda D, Moy CS, et al: Bilateral deep brain stimulation vs best medical therapy for patients with advanced Parkinson disease: a randomized controlled trial. JAMA 2009;301:63-73. 
44 Williams A, Gill S, Varma T: Deep brain stimulation plus best medical therapy versus best medical therapy alone for advanced Parkinson's disease (PD SURG trial): a randomised, open-label trial. Lancet Neurol 2010; 9:581-591.

45 Jenkinson C, Fitzpatrick R, Peto V, Greenhall R, Hyman N: The Parkinson's Disease Questionnaire (PDQ-39): development and validation of a Parkinson's disease summary index score. Age Ageing 1997;26:353357.

-46 Goetz CG, Stebbins GT, Tilley BC: Calibration of unified Parkinson's disease rating scale scores to Movement Disorder Society-unified Parkinson's disease rating scale scores. Mov Disord 2012;27:1239-1242.

-47 Okun MS, Fernandez HH, Wu SS, Kirsch-Darrow L, Bowers D, Bova F, Suelter M, Jacobson CE, Wang X, Gordon CW Jr, et al: Cognition and mood in Parkinson's disease in subthalamic nucleus versus globus pallidus interna deep brain stimulation: the COMPARE trial. Ann Neurol 2009;65:586-595.

-48 Albanese A, Asmus F, Bhatia KP, Elia AE, Elibol B, Filippini G, Gasser T, Krauss JK, Nardocci N, Newton A, et al: EFNS guidelines on diagnosis and treatment of primary dystonias. Eur J Neurol 2011;18:5-18.

49 Bhidayasiri R, Tarsy D: Treatment of dystonia. Expert Rev Neurother 2006;6:863-886.

50 Sellal F, Hirsch E, Barth P, Blond S, Marescaux C: A case of symptomatic hemidystonia improved by ventroposterolateral thalamic electrostimulation. Mov Disord 1993;8:515-518.

51 Eltahawy HA, Saint-Cyr J, Giladi N, Lang AE, Lozano AM: Primary dystonia is more responsive than secondary dystonia to pallidal interventions: outcome after pallidotomy or pallidal deep brain stimulation. Neurosurgery 2004;54:613-619, discussion 619-621.

-52 Yoshor D, Hamilton WJ, Ondo W, Jankovic J, Grossman RG: Comparison of thalamotomy and pallidotomy for the treatment of dystonia. Neurosurgery 2001;48:818-824, discussion 824-826.

53 Kupsch A, Benecke R, Muller J, Trottenberg T, Schneider GH, Poewe W, Eisner W, Wolters A, Muller JU, Deuschl G, et al: Pallidal deep-brain stimulation in primary generalized or segmental dystonia. New Engl J Med 2006; 355:1978-1990.

54 Vidailhet M, Vercueil L, Houeto JL, Krystkowiak P, Benabid AL, Cornu P, Lagrange C, Tezenas du Montcel S, Dormont D, Grand S, et al: Bilateral deep-brain stimulation of the globus pallidus in primary generalized dystonia. New Engl J Med 2005;352:459-467.

55 Isaias IU, Alterman R, Tagliati M: Deep brain stimulation for primary generalized dystonia: long-term outcomes. Arch Neurol 2009;66:465-470.

56 Isaias IU, Volkmann J, Kupsch A, Burgunder JM, Ostrem JL, Alterman RL, Mehdorn HM, Schonecker T, Krauss JK, Starr P, et al: Factors predicting protracted improvement after pallidal DBS for primary dystonia: the role of age and disease duration. J Neurol 2011;258:1469-1476.

57 Vidailhet M, Vercueil L, Houeto JL, Krystkowiak P, Lagrange C, Yelnik J, Bardinet E, Benabid AL, Navarro S, Dormont D, et al: Bilateral, pallidal, deep-brain stimulation in primary generalised dystonia: a prospective 3-year follow-up study. Lancet Neurol 2007;6:223-229.

58 Volkmann J, Wolters A, Kupsch A, Muller J, Kuhn AA, Schneider GH, Poewe W, Hering S, Eisner W, Muller JU, et al: Pallidal deep brain stimulation in patients with primary generalised or segmental dystonia: 5-year followup of a randomised trial. Lancet Neurol 2012;11:1029-1038.

59 Burke RE, Fahn S, Marsden CD, Bressman SB, Moskowitz C, Friedman J: Validity and reliability of a rating scale for the primary torsion dystonias. Neurology 1985;35:73.

60 Isaias IU, Alterman RL, Tagliati M: Outcome predictors of pallidal stimulation in patients with primary dystonia: the role of disease duration. Brain 2008;131:1895-1902.

61 Ruscio AM, Stein DJ, Chiu WT, Kessler RC: The epidemiology of obsessive-compulsive disorder in the National Comorbidity Survey Replication. Mol Psychiatry 2010;15:53-63.

62 Pallanti S, Quercioli L: Treatment-refractory obsessive-compulsive disorder: methodological issues, operational definitions and therapeutic lines. Prog Neuropsychopharmacol Biol Psychiatry 2006;30:400-412.

63 Mian MK, Campos M, Sheth SA, Eskandar EN: Deep brain stimulation for obsessive-compulsive disorder: past, present, and future. Neurosurg Focus 2010;29:E10.

64 Nuttin B, Cosyns P, Demeulemeester H, Gybels J, Meyerson B: Electrical stimulation in anterior limbs of internal capsules in patients with obsessive-compulsive disorder. Lancet 1999;354:1526.

65 Burdick A, Goodman WK, Foote KD: Deep brain stimulation for refractory obsessive-compulsive disorder. Front Biosci 2009;14:1880-1890.

66 Goodman WK, Foote KD, Greenberg BD, Ricciuti N, Bauer R, Ward H, Shapira NA, Wu SS, Hill CL, Rasmussen SA, et al: Deep brain stimulation for intractable obsessive compulsive disorder: pilot study using a blinded, staggered-onset design. Biol Psychiatry 2010;67:535-542.

67 Greenberg BD, Gabriels LA, Malone DA Jr, Rezai AR, Friehs GM, Okun MS, Shapira NA, Foote KD, Cosyns PR, Kubu CS, et al: Deep brain stimulation of the ventral internal capsule/ventral striatum for obsessive-compulsive disorder: worldwide experience. Mol Psychiatry 2010;15:64-79.

68 Haynes WIA, Mallet L: High-frequency stimulation of deep brain structures in obsessive-compulsive disorder: the search for a valid circuit. Eur J Neurosci 2010;32:1118-1127.

69 Koning P, Figee M, Munckhof P, Schuurman PR, Denys D: Current status of deep brain stimulation for obsessivecompulsive disorder: a clinical review of different targets. Curr Psychiatry Rep 2011;13:274-282.

70 Greenberg BD, Malone DA, Friehs GM, Rezai AR, Kubu CS, Malloy PF, Salloway SP, Okun MS, Goodman WK, Rasmussen SA: Three-year outcomes in deep brain stimulation for highly resistant obsessive-compulsive disorder. Neuropsychopharmacology 2006;31:2384-2393. 
71 Nuttin BJ, Gabriëls LA, Cosyns PR, Meyerson BA, Andréewitch S, Sunaert SG, Maes AF, Dupont PJ, Gybels JM, Gielen F, et al: Long-term electrical capsular stimulation in patients with obsessive-compulsive disorder. Neurosurgery 2003;52:1263-1274.

72 Greenberg BD, Askland KD, Carpenter LL: DBS for neuropsychiatric disorders. Front Biosci 2008;13:46384648.

73 Fontaine D, Mattei V, Borg M, von Langsdorff D, Magnie M-N, Chanalet S, Robert P, Paquis P: Effect of subthalamic nucleus stimulation on obsessive-compulsive disorder in a patient with Parkinson disease. J Neurosurg 2004;100:1084-1086.

74 Mallet L, Mesnage V, Houeto J-L, Pelissolo A, Yelnik J, Behar C, Gargiulo M, Welter M-L, Bonnet A-M, Pillon B, et al: Compulsions, Parkinson's disease, and stimulation. Lancet 2002;360:1302-1304.

75 Mallet L, Polosan M, Jaafari N: Subthalamic nucleus stimulation in severe obsessive-compulsive disorder. New Engl J Med 2008;359:2121-2134.

76 Sander JW: The epidemiology of epilepsy revisited. Curr Opin Neurol 2003;16:165-170.

77 de Tisi J, Bell GS, Peacock JL, McEvoy AW, Harkness WFJ, Sander JW, Duncan JS: The long-term outcome of adult epilepsy surgery, patterns of seizure remission, and relapse: a cohort study. Lancet 378:1388-1395.

78 Handforth A, DeGiorgio CM, Schachter SC, Uthman BM, Naritoku DK, Tecoma ES, Henry TR, Collins SD, Vaughn BV, Gilmartin RC, et al: Vagus nerve stimulation therapy for partial-onset seizures: a randomized activecontrol trial. Neurology 1998;51:48-55.

79 Cooper IS, Amin I, Gilman S: The effect of chronic cerebellar stimulation upon epilepsy in man. Trans Am Neurol Assoc 1973:98:192-196.

80 Lega BC, Halpern CH, Jaggi JL, Baltuch GH: Deep brain stimulation in the treatment of refractory epilepsy: update on current data and future directions. Neurobiol Dis 2010;38:354-360.

81 Fisher R, Salanova V, Witt T, Worth R, Henry T, Gross R, Oommen K, Osorio I, Nazzaro J, Labar D, et al: Electrical stimulation of the anterior nucleus of thalamus for treatment of refractory epilepsy. Epilepsia 2010;51:899908.

82 Theodore WH, Fisher RS: Brain stimulation for epilepsy. Lancet Neurol 2004;3:111-118.

- 83 Blomstedt P, Hariz MI: Deep brain stimulation for movement disorders before DBS for movement disorders. Parkinsonism Relat Disord 2010;16:429-433.

84 Levy R, Deer TR, Henderson J: Intracranial neurostimulation for pain control: a review. Pain Physician 2010; 13:157-165.

85 Bittar RG, Kar-Purkayastha I, Owen SL, Bear RE, Green A, Wang S, Aziz TZ: Deep brain stimulation for pain relief: a meta-analysis. J Clin Neurosci 2005;12:515-519.

86 Hamani C, Schwalb JM, Rezai AR, Dostrovsky JO, Davis KD, Lozano AM: Deep brain stimulation for chronic neuropathic pain: long-term outcome and the incidence of insertional effect. Pain 2006;125:188-196.

87 Adams JE, Hosobuchi Y, Fields HL: Stimulation of internal capsule for relief of chronic pain. J Neurosurg 1974; 41:740-744.

88 Owen SL, Green AL, Stein JF, Aziz TZ: Deep brain stimulation for the alleviation of post-stroke neuropathic pain. Pain 2006;120:202-206.

89 Cordella R, Franzini A, La Mantia L, Marras C, Erbetta A, Broggi G: Hypothalamic stimulation for trigeminal neuralgia in multiple sclerosis patients: efficacy on the paroxysmal ophthalmic pain. Mult Scler 2009;15: 1322-1328.

90 Levy RM, Lamb S, Adams JE: Treatment of chronic pain by deep brain stimulation: long-term follow-up and review of the literature. Neurosurgery 1987;21:885-893.

91 Fontaine D, Lanteri-Minet M, Ouchchane L, Lazorthes Y, Mertens P, Blond S, Geraud G, Fabre N, Navez M, Lucas C, et al: Anatomical location of effective deep brain stimulation electrodes in chronic cluster headache. Brain 2010;133:1214-1223.

92 Cruccu G, Aziz TZ, Garcia-Larrea L, Hansson P, Jensen TS, Lefaucheur JP, Simpson BA, Taylor RS: EFNS guidelines on neurostimulation therapy for neuropathic pain. Eur J Neurol 2007;14:952-970.

93 Belmaker RH, Agam G: Major depressive disorder. New Engl J Med 2008;358:55-68.

94 Mayberg HS, Lozano AM, Voon V, McNeely HE, Seminowicz D, Hamani C, Schwalb JM, Kennedy SH: Deep brain stimulation for treatment-resistant depression. Neuron 2005;45:651-660.

95 Lozano AM, Giacobbe P, Hamani C, Rizvi SJ, Kennedy SH, Kolivakis TT, Debonnel G, Sadikot AF, Lam RW, Howard AK, et al: A multicenter pilot study of subcallosal cingulate area deep brain stimulation for treatmentresistant depression. J Neurosurg 2012;116:315-322.

96 Lozano AM, Mayberg HS, Giacobbe P, Hamani C, Craddock RC, Kennedy SH: Subcallosal cingulate gyrus deep brain stimulation for treatment-resistant depression. Biol Psychiatry 2008;64:461-467.

97 Kennedy SH, Giacobbe P, Rizvi SJ, Placenza FM, Nishikawa Y, Mayberg HS, Lozano AM: Deep brain stimulation for treatment-resistant depression: follow-up after 3 to 6 years. Am J Psychiatry 2011;168:502510.

98 Jimenez F, Velasco F, Salin-Pascual R, Hernandez JA, Velasco M, Criales JL, Nicolini H: A patient with a resistant major depression disorder treated with deep brain stimulation in the inferior thalamic peduncle. Neurosurgery 2005;57:585-593, discussion 585-593.

99 Aouizerate B, Cuny E, Martin-Guehl C, Guehl D, Amieva H, Benazzouz A, Fabrigoule C, Allard M, Rougier A, Bioulac B, et al: Deep brain stimulation of the ventral caudate nucleus in the treatment of obsessive-compulsive disorder and major depression. J Neurosurg 2004;101:682-686. 
100 Malone DA Jr, Dougherty DD, Rezai AR, Carpenter LL, Friehs GM, Eskandar EN, Rauch SL, Rasmussen SA, Machado AG, Kubu CS, et al: Deep brain stimulation of the ventral capsule/ventral striatum for treatmentresistant depression. Biol Psychiatry 2009;65:267-275.

101 Bewernick BH, Hurlemann R, Matusch A, Kayser S, Grubert C, Hadrysiewicz B, Axmacher N, Lemke M, CooperMahkorn D, Cohen MX, et al: Nucleus accumbens deep brain stimulation decreases ratings of depression and anxiety in treatment-resistant depression. Biol Psychiatry 2010;67:110-116.

102 Sartorius A, Kiening KL, Kirsch P, von Gall CC, Haberkorn U, Unterberg AW, Henn FA, Meyer-Lindenberg A: Remission of major depression under deep brain stimulation of the lateral habenula in a therapy-refractory patient. Biol Psychiatry 2010;67:e9-e11.

103 Freeman R, Fast D, Burd L: An international perspective on Tourette syndrome: selected findings from 3,500 individuals in 22 countries. Dev Med Child Neurol 2000;42:436-447.

104 Muller-Vahl KR: Surgical treatment of Tourette syndrome. Neurosci Biobehav Rev 2013;37:1178-1185.

105 Houeto JL, Karachi C, Mallet L, Pillon B, Yelnik J, Mesnage V, Welter ML, Navarro S, Pelissolo A, Damier P, et al: Tourette's syndrome and deep brain stimulation. J Neurol Neurosurg Psychiatry 2005;76:992-995.

106 Servello D, Sassi M, Brambilla A, Defendi S, Porta M: Long-term, post-deep brain stimulation management of a series of 36 patients affected with refractory Gilles de la Tourette syndrome. Neuromodulation 2010;13: 187-194.

107 Vandewalle V, van der Linden C, Groenewegen HJ, Caemaert J: Stereotactic treatment of Gilles de la Tourette syndrome by high frequency stimulation of thalamus. Lancet 1999;353:724.

108 Welter ML, Mallet L, Houeto JL, Karachi C, Czernecki V, Cornu P, Navarro S, Pidoux B, Dormont D, Bardinet E, et al: Internal pallidal and thalamic stimulation in patients with Tourette syndrome. Arch Neurol 2008;65: 952-957.

109 Martinez-Torres I, Hariz MI, Zrinzo L, Foltynie T, Limousin P: Improvement of tics after subthalamic nucleus deep brain stimulation. Neurology 2009;72:1787-1789.

110 Ackermans L, Duits A, van der Linden C, Tijssen M, Schruers K, Temel Y, Kleijer M, Nederveen P, Bruggeman $\mathrm{R}$, Tromp S, et al: Double-blind clinical trial of thalamic stimulation in patients with Tourette syndrome. Brain 2011;134:832-844.

111 Kuhn J, Lenartz D, Mai J, Huff W, Lee SH, Koulousakis A, Klosterkoetter J, Sturm V: Deep brain stimulation of the nucleus accumbens and the internal capsule in therapeutically refractory Tourette syndrome. J Neurol 2007;254:963-965.

112 Flaherty AW, Williams ZM, Amirnovin R, Kasper E, Rauch SL, Cosgrove GR, Eskandar EN: Deep brain stimulation of the anterior internal capsule for the treatment of Tourette syndrome: technical case report. Neurosurgery 2005;57:E403, discussion E403.

113 Servello D, Sassi M, Brambilla A, Porta M, Haq I, Foote K, Okun M: De novo and rescue DBS leads for refractory Tourette syndrome patients with severe comorbid OCD: a multiple case report. J Neurol 2009;256:15331539.

114 Moro E, Lang AE, Strafella AP, Poon Y-YW, Arango PM, Dagher A, Hutchison WD, Lozano AM: Bilateral globus pallidus stimulation for Huntington's disease. Ann Neurol 2004;56:290-294.

115 Hebb MO, Garcia R, Gaudet P, Mendez IM: Bilateral stimulation of the globus pallidus internus to treat choreathetosis in Huntington's disease: technical case report. Neurosurgery 2006;58:E383.

116 Biolsi B, Cif L, Fertit HE, Robles SG, Coubes P: Long-term follow-up of Huntington disease treated by bilateral deep brain stimulation of the internal globus pallidus. J Neurosurg 2008;109:130-132.

117 Fasano A, Mazzone P, Piano C, Quaranta D, Soleti F, Bentivoglio AR: GPi-DBS in Huntington's disease: results on motor function and cognition in a 72-year-old case. Mov Disord 2008;23:1289-1292.

118 Taghva A, Corrigan JD, Rezai AR: Obesity and brain addiction circuitry: implications for deep brain stimulation. Neurosurgery 2012;71:224-238.

119 Quaade F, Yærnet K, Larsson S: Stereotaxic stimulation and electrocoagulation of the lateral hypothalamus in obese humans. Acta Neurochir 1974;30:111-117.

120 Wilent WB, Oh MY, Buetefisch CM, Bailes JE, Cantella D, Angle C, Whiting DM: Induction of panic attack by stimulation of the ventromedial hypothalamus. J Neurosurg 2010;112:1295-1298.

121 Halpern CH, Wolf JA, Bale TL, Stunkard AJ, Danish SF, Grossman M, Jaggi JL, Grady MS, Baltuch GH: Deep brain stimulation in the treatment of obesity. J Neurosurg 2008;109:625-634.

-122 Hamani C, McAndrews MP, Cohn M, Oh M, Zumsteg D, Shapiro CM, Wennberg RA, Lozano AM: Memory enhancement induced by hypothalamic/fornix deep brain stimulation. Ann Neurol 2008;63:119-123.

-123 Pisapia JM, Halpern CH, Williams NN, Wadden TA, Baltuch GH, Stein SC: Deep brain stimulation compared with bariatric surgery for the treatment of morbid obesity: a decision analysis study. Neurosurg Focus 2010; 29:E15.

124 Bannier S, Montaurier C, Derost PP, Ulla M, Lemaire JJ, Boirie Y, Morio B, Durif F: Overweight after deep brain stimulation of the subthalamic nucleus in Parkinson disease: long-term follow-up. J Neurol Neurosurg Psychiatry 2009;80:484-488.

125 Mantione M, van de Brink W, Schuurman PR, Denys D: Smoking cessation and weight loss after chronic deep brain stimulation of the nucleus accumbens: therapeutic and research implications: case report. Neurosurgery 2010;66:E218, discussion E218.

126 Voges J, Muller U, Bogerts B, Munte T, Heinze HJ: Deep brain stimulation surgery for alcohol addiction. World Neurosurg, E-pub ahead of print. 
127 Zhou H, Xu J, Jiang J: Deep brain stimulation of nucleus accumbens on heroin-seeking behaviors: a case report. Biol Psychiatry 2011;69:e41-e42.

128 Reitz C, Brayne C, Mayeux R: Epidemiology of Alzheimer disease. Nat Rev Neurol 2011;7:137-152.

129 Laxton AW, Tang-Wai DF, McAndrews MP, Zumsteg D, Wennberg R, Keren R, Wherrett J, Naglie G, Hamani C, Smith GS, et al: A phase I trial of deep brain stimulation of memory circuits in Alzheimer's disease. Ann Neurol 2010;68:521-534.

130 Smith GS, Laxton AW, Tang-Wai DF, McAndrews MP, Diaconescu AO, Workman CI, Lozano AM: Increased cerebral metabolism after 1 year of deep brain stimulation in Alzheimer disease. Arch Neurol 2012;69:11411148.

131 Giacino JT, Kalmar K: Diagnostic and prognostic guidelines for the vegetative and minimally conscious states. Neuropsychol Rehabil 2005;15:166-174.

132 Schiff ND, Giacino JT, Kalmar K, Victor JD, Baker K, Gerber M, Fritz B, Eisenberg B, Biondi T, O'Connor J, et al: Behavioural improvements with thalamic stimulation after severe traumatic brain injury. Nature 2007;448: 600-603.

133 Yamamoto T, Katayama Y, Kobayashi K, Oshima H, Fukaya C, Tsubokawa T: Deep brain stimulation for the treatment of vegetative state. Eur J Neurosci 2010;32:1145-1151.

134 Giacino J, Fins JJ, Machado A, Schiff ND: Central thalamic deep brain stimulation to promote recovery from chronic posttraumatic minimally conscious state: challenges and opportunities. Neuromodulation 2012;15: 339-349.

135 Zrinzo L, Foltynie T, Limousin P, Hariz MI: Reducing hemorrhagic complications in functional neurosurgery: a large case series and systematic literature review. J Neurosurg 2012;116:84-94.

136 Pouratian N, Reames DL, Frysinger R, Elias WJ: Comprehensive analysis of risk factors for seizures after deep brain stimulation surgery. Clinical article. J Neurosurg 2011;115:310-315.

137 Coley E, Farhadi R, Lewis S, Whittle IR: The incidence of seizures following deep brain stimulating electrode implantation for movement disorders, pain and psychiatric conditions. Br J Neurosurg 2009;23:179-183.

138 Baizabal Carvallo JF, Simpson R, Jankovic J: Diagnosis and treatment of complications related to deep brain stimulation hardware. Mov Disord 2011;26:1398-1406.

139 Blomstedt P, Hariz MI: Are complications less common in deep brain stimulation than in ablative procedures for movement disorders? Stereotact Funct Neurosurg 2006;84:72-81.

140 Boviatsis EJ, Stavrinou LC, Themistocleous M, Kouyialis AT, Sakas DE: Surgical and hardware complications of deep brain stimulation. A seven-year experience and review of the literature. Acta Neurochir 2010;152:20532062.

141 Chan DT, Zhu XL, Yeung JH, Mok VC, Wong E, Lau C, Wong R, Lau C, Poon WS: Complications of deep brain stimulation: a collective review. Asian J Surg 2009;32:258-263.

142 Doshi PK: Long-term surgical and hardware-related complications of deep brain stimulation. Stereotact Funct Neurosurg 2011;89:89-95.

143 Voges J, Waerzeggers Y, Maarouf M, Lehrke R, Koulousakis A, Lenartz D, Sturm V: Deep-brain stimulation: long-term analysis of complications caused by hardware and surgery - experiences from a single centre. J Neurol Neurosurg Psychiatry 2006;77:868-872.

144 Hamani C, Lozano AM: Hardware-related complications of deep brain stimulation: a review of the published literature. Stereotact Funct Neurosurg 2006;84:248-251.

145 Fenoy AJ, Simpson RK: Management of device-related wound complications in deep brain stimulation surgery. J Neurosurg 2012;116:1324-1332.

146 Grill WM: Safety considerations for deep brain stimulation: review and analysis. Expert Rev Med Devices 2005;2:409-420.

147 Gubellini P, Salin P, Kerkerian-Le Goff L, Baunez C: Deep brain stimulation in neurological diseases and exper-

imental models: from molecule to complex behavior. Prog Neurobiol 2009;89:79-123. 